УДК 341.645 .2

\author{
М. В. Лочицький, Т. П. Мiнка
}

\title{
АКТУАЛЬНІ ПИТАННЯ ВДОСКОНАЛЕННЯ ЗАКОНОДАВСТВА 3 ОФОРМЛЕННЯ МАТЕРІАЛІВ ПРО АДМІНІСТРАТИВНІ ПРАВОПОРУШЕННЯ ОРГАНАМИ ВНУТРІШНІХ СПРАВ
}

Реформування органів внутрішніх справ неможливо уявити без реформування інституту алміністративної відповідальності, який у незалежній Украіні не зазнавав грунтовних змін.

Чинний Кодекс України про адміністративні правопорушення (далі КУпАП) був прийнятий у радянські часи (1984р.). Із того часу в нього внесено величезну кількість змін, які не мають системного характеру, відзначаються надмірною деталізацією й необгрунтовано перетворюють адміністративне деліктне законодавство в зібрання казуальних правил. Процедури притягнення до відповідальності за вчинення адміністративних проступків не відповідають багатьом вимогам до таких процедур у частині дотримання прав людини і основоположних свобод, зокрема положенням Рекомендаціі № R (91) 1 Комітету Міністрів Ради Європи державам-цленам стосовно адміністративних санкцій від 13 лютого 1991 р. [1].

Також це стосується правильного оформлення протоколу у справі про адміністративне правопорушення, адже ця процесуальна дія має велике значення для повного й об'єктивного розгляду адміністративної справи та винесення законного рішення, обгрунтованості притягнення правопорушника до адміністративної відповідальності. Порушення, допушені під час складання протоколу про адміністративне правопорушення, призводять до залишення таких протоколів без розгляду уповноваженими особами, які виносять постанови у справі, до повернення матеріалів на доопрацювання або закриття адміністративної справи. Це, у свою чергу, впливає на сплив строків притягнення до адміністративної відповідальності, передбачених ст. 38 КУПАП, і, як наслідок, до безкарності осіб, котрі вчинили адміністративне правопорушення.

Проблемами процесуальної складової адміністративно-деліктного провадження свого часу займались Ю.П. Битяк, А.С. Васильєв, І.П. Голосніченко, С.Т. Гончарук, Є.В. Додін, В.В. Зуй, В.К. Колпаков, А.Т. Комзюк, Д.М. Лук'янешь, Р.В. Миронюк та багато інших. Але, незважаючи на знач- 
ну увагу, яку приділяють науковці питанням адміністративної відповідальності, проблеми правильності складання протоколів про адміністративні правопорушення досі залишаються недостатньо дослідженими і майже не вирішеними.

Тому метою статті $\epsilon$ науковий аналіз проблем застосування норм КУПАП, які регулюють процедури складання протоколу про адміністративне правопорушення, та розроблення пропозицій щодо вдосконаленню діяльності органів внутрішніх справ із застосування відповідного законодавства.

3 аналізу положень КУПАП можна зробити висновок, що протокол про адміністративне правопорушення $€$ основним процесуальним документом у справах про адміністративні правопорушення, а також головним джерелом доказу вчиненого адміністративного правопорушення.

Протокол про адміністративне правопорушення $€$ доказом у справі про адміністративне правопорушення, на підставі якого встановлюється наявність чи відсутність адміністративного правопорушення, винність особи в його вчиненні й інші обставини, що мають значення для правильного вирішення справи. На такій позиції стоїть і правозастосовна практика, оскільки під час розгляду справ про адміністративні правопорушення відповідний орган (посадова особа) надає правову оцінку обставинам, викладеним у протоколі, аналізує сам протокол, у своїх постановах суди часто пишуть, шо вина правопорушника підтверджується протоколом [2, с. 52].

Процесуальні вимоги шодо змісту протоколу про адміністративне правопорушення визначені в нормах ст. 256 КУпАП. Процесуальний порядок складання протоколу про адміністративне правопорушення працівниками органів внутрішніх справ деталізовано у відомчих нормативно-правових актах, зокрема в наказах МBC України: «Про питання шодо застосування адміністративного законодавства України органами внутрішніх справ» від 04.10.2013 р. № 950, «Про затвердження Інструкції з оформлення працівниками Державтоінспекціі $\mathrm{MBC}$ матеріалів про адміністративні правопорушення у сфері забезпечення безпеки дорожнього руху» віл 26.02 .2009 р. № 75 .

Крім установлених процесуальних вимог щодо протоколу про адміністративне правопорушення, він повинен відповідати й змістовим вимогам, які можна поділити на такі групи: 1) відомості про особу, яка склала протокол про адміністративне правопорушення; 2) відомості про особу правопорушника; 3) відомості про роз'яснення правопорушнику його прав та обов'язків; 4) відомості про обставини вчиненого адміністративного правопорушення; 5) відомості про осіб, присутніх під час складання протоколу (свідки, поняті), і про інші докази, які підтверджують вину правопорушника.

Усі ці дані мають важливе значення, їх не можна вважати лише формальністю. Уповноважена особа, котра здійснює розслідування, мусить ретельно розібратися в характері правопорушення й правильно кваліфікувати дії винного. У протоколі необхідно об'єктивно зазначити ті обставини, які свідчать про наявність адміністративного проступку та його характер [3, c. 190]. 
Однією з обов'язкових вимог до протоколу про адміністративне правопорушення $є$ зазначення відомостей про особу, яка склала цей протокол. Згідно зі ст. 256 Кодексу адміністративного судочинства України, до цих відомостей належать дані стосовно посади, прізвища, ім'я по батькові відповідної посадової особи, а також їі підпис. Відсутність ших відомостей у протоколі $є$ підставою для визнання такого протоколу недійсним і закриття справи, адже невідомо, чи був він складений уповноваженою на це посадовою особою чи ні.

Як свідчить судова практика $[4 ; 5 ; 6 ; 7]$, працівники міліції, які складають протоколи про адміністративне правопорушення, дуже часто нерозбірливо вказують своє прізвише, ім'я по батькові, найменування підрозділу, у якому працюють, шо ускладнює для особи, котра розглядає цей протокол, ідентифікашію особи, яка його склала. Тому вважаємо, шо у бланку протоколу про адміністративне правопорушення, який міститься в додатках до наказів МВС України від 04.10.2013 р. № 950 та 26.02.2009 р. № 75 варто окремими рядками (блоками) передбачити відомості про прізвище, ім'я по батькові особи, котра склала протокол, відомості про посаду, що має вказуватися повністю, без скорочень, а також дані про номер посвідчення. Такий перелік відомостей про особу надасть змогу з великою вірогідністю сказати, шо саме ця особа склала протокол про адміністративне правопорушення.

Документи, згідно з якими правопорушники притягуються до адміністративної відповідальності, не завжди містять налтежні реквізити, $є$ випадки, коли протоколи складаються неграмотно й несвоєчасно, 3 цими документами не завжди ознайомлюються особи, притягнуті до відповідальності. ᄂерез неточні та неправильні записи у протоколах про місце реєстрації правопорушників або фактичне місце проживання правопорушників судом витрачаються додаткові кошти на повторні виклики. Крім того, це призводить до пропуску строків накладення адміністративних стягнень [8]. Як наслідок, особа, котра вчинила адміністративне правопорушення, не несе відповідальності за свій протиправний учинок.

Наступна група вимог пов'язана із закріпленням відомостей про роз'яснення правопорушнику його прав і обов'язків. У бланках протоколів про адміністративне правопорушення, які передбачені наказами $\mathrm{MBC}$ України від 04.10 .2013 р. № 950 та 26.02.2009 р. № 75, міститься інформація про те, що правопорушнику роз'яснюються передбачені ст. ст. 55, 56, 59, 63 Конституції України і ст. 268 КУпАП права й обов'язки, а також право й можливість отримати безоплатну вторинну правову допомогу відповідно до Закону України «Про безоплатну правову допомогу». Роз'яснення прав та обов'язків правопорушнику є обов'язковою процесуальною дією, нехтування якою може призвести до повернення протоколу про адміністративне правопорушення й залишення справи без розгляду.

Наприклад, голова Апеляційного суду м. Кисва скасував постанову Солом'янського районного суду м. Києва від 01 серпня 2002 р. про притягнення громадянина до адміністративної відповідальності за ст. 124 КУПАП 
у зв'язку з тим, шо місцевий суд на підтвердження його вини послався на протокол про адміністративне правопорушення, який не відповідає вимогам ст. $256 \mathrm{KУ}$ пАП, оскільки не містить пояснень порушника (у протоколі $\epsilon$ відмітка про те, шо пояснення містяться на окремому аркуші, однак цей аркуш у матеріалах справи відсутній); не зазначені прізвиша й адреси свідків і потерпілих; протоко.т не підписаний самим громадянином. Крім того, у протоколі немає відмітки про роз'яснення порушникові його прав і обов'язків, передбачених ст. 268 КУпАП. Інші докази, передбачені ст. 251 КУПАП, у постанові не наведені й у матеріалах справи відсутні [9].

Наступним, на нашу думку, одним із головних, моментом, на який хотілося б звернути увагу, $\epsilon$ правильне й точне описання в протоколі про адміністративне правопорушення дій, шо вчинила особа, котра притягується до адміністративної відповідальності, адже від цього залежить правильність кваліфікації вчиненого адміністративного правопорушення.

Узагальнення судової практики свідчить, що працівники органів внутрішніх справ під час складання протоколів про адміністративне правопорушення дуже часто не зазначають місця вчинення правопорушення та неповно або взагалі не викладають його суть; не завжди конкретизують форму вчинення правопорушення; інколи відмову особи, яка вчинила правопорушення, від підписання протоколу не засвідчують підписами понятих; не зазначають прізвиша, адреси свідків і потерпілих (якшо вказують, то часто свідками бувають працівники міліціі); відсутні пояснення правопорушника й посилання на нормативний акт, яким передбачено відповідальність за вчинене правопорушення; відсутні документи, що підтверджують медичний огляд особи, хоча із протоколу та рапортів убачається, що правопорушник перебував у стані алкогольного сп'яніння; протокол про адміністративне правопорушення містить виправлення, шо недопустимо, тошо [5].

Дуже часто внаслідок неправильного й неналежного оформлення працівниками органів внутрішніх справ протоколів про адміністративне правопорушення правопорушники уникали відповідальності, передбаченої законом. Це пов'язано з неправильним оформленням у протоколі суті скоєного правопорушення, тобто об'єктивної сторони правопорушення, та висвітлення кваліфікуючих ознак учиненого правопорушення. Так, наприклад, складаючи протокол за ст. 173 КУПАП «Дрібне хуліганство», дільничний інспектор міліції зазначив, шо особа виражалась у громадському місці брудною лайкою, хоча об'єктивна сторона цього правопорушення передбачає відповідальність за нецензурну лайку. 3 цього приводу суд справедливо зазначив у своєму рішенні: «Протокол не містить зазначення, що ОСОБА_1 виражався нецензурною лайкою, а поняття «брудна» лайка диспозиція статті не передбачає» [10]. Тому судді не залишалось нічого іншого, як винести постанову про закриття справи за відсутністю в діях особи складу адміністративного правопорушення.

Аналогічна ситуація склалась в іншій справі. Так, розглядаючи адміністративний протокол серії АБ2 № 245167 від 20.11.2014 р. за ст. 173 
КУПАП, Бродівський районний суд. Львівської області у своєму рішенні справедливо зазначив: «Розглянувши матеріали справи про адміністративне правопорушення, суддя дійшла висновку, шо в џіях ОСОБА_1 відсутній склад адміністративного правопорушення, передбаченого ст. 173 КУПАП, оскільки в протоколі зазначено дії, шо не відповідають ст. 173 КУПАП, із змісту якої вбачається, що порушенням $\epsilon$ нецензурна лайка в громадських місцях, образливе чіпляння до громадян та інші подібні дії, що порушують громадський порядок і спокій громадян» [11].

Проблеми правильної кваліфікації вчиненого адміністративного правопорушення можна спостерігати в справах про адміністративні правопо-

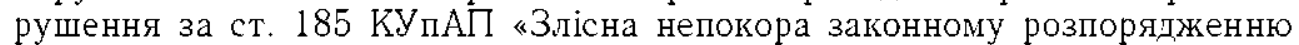
або вимозі працівника міліції, члена громадського формування 3 охорони громадського порядку і державного кордону, військовослужбовця». Складаючи протоколи про адміністративні правопорушення, працівники мілішії, намагаючись описати суть скоєного правопорушення, формулюють протиправні дії правопорушника, зовсім не в межах об'сктивної сторони правопорушення. Так, наприклад, злісну непокору особ́и характеризують так: «... зроблено усне зауваження, на яке вони (правопорушники - авт.) не відреагували», «почав (правопорушник - авт.) поводити себе неадекватно», «на вимогу присісти в крісло відмовився» тошо $[12 ; 13]$. Неправильність опису протиправних дій особи, невказування кваліфікуючих ознак учиненого правопорушення призводить до винесення судом постанови про закриття справи у зв'язку з відсутністю в діях особи складу адміністративного правопорушення.

На нашу думку, вирішити зазначену проблему можливо за допомогою внесення змін до зразків протоколів про адміністративне правопорушення, які містяться в додатках до наказів МВС України від 04.10.2013р. № 950 i 26.02 .2009 p. № 75 , у частині більш зручного розташування інформаційних, описових складових. Конкретизація багатьох інформаційних даних, зокрема про особу, яка склала протокол, особу правопорушника, місце, час скоєння правопорушення, опис протиправних дій тошо має здійснюватися в окремих місцях, відведених у протоколі про адміністративне правопорушення шляхом заповнення відповідних пунктів. Тобто, особа, котра складає протокол, буде обирати з наведеного відповідний пункт, проставляючи просту відмітку (галочку, хрестик), а інші дані заповнювати, відповідаючи на відкриті питання.

Зазначені зміни, на нашу думку, сприятимуть зменшенню помилок прашівниками органів внутрішніх справ, які вони допускають під час складання протоколу про адміністративне правопорушення. Запропоновані нами зміни допоможуть належним чином оформлювати протокол про адміністративне правопорушення навіть особам, котрі не мають достатнього досвіду та навичок у цьому, значно скоротять час на його скјадання.

Отже, для практичного запровадження вишезазначених пропозицій нами у статті запропоновано зразок протоколу про адміністративне правопорушення. 
Для втілення зазначених пропозицій доречно було б додатково розглянути питання шодо запровајження нових зразків бланків протоколів про адміністративне правопорушення, які (зразки протоколів) варто систематизувати за типами, шо дасть змогу прашівникам органів внутрішніх справ обирати потрібний вид б.ланка протоколу для певного виду адміністративного правопорушення.

Не зайвим буде в майбутньому запровадити електронну форму протоколу про адміністративне правопорушення, передбачивши можливість складання його в електронному вигляді з можливістю підписувати його правопорушником за допомогою власної ID-картки (посвідчення особи), запровадження яких передбачено Постановою Кабінету Міністрів Украйни «Деякі питання виконання Закону України «Про Єдиний державний демографічний реєстр та документи, шо підтверджують громадянство України, посвідчують особу чи їі спешіальний статус» від 13.03 .2013 p. № 185 [14].

MIHICTEРСТВО ВНУТРІШНІХ СПРАВ УКРӒ̈НИ

Дніпропетровське міське управління ГУМВС України в Дніпропетровській області

ПРОТОКОЛ

про адміністративне правопорушення за ст. $173 \mathrm{KУ} \cap \mathrm{A \Pi}$

Місце складання

ㅁㅁㅁㅁㅁㅁㅁㅁㅁㅁㅁ

Дата складання $\square \square \square \square \square \square \square \square \square \square \square \square \square \square \square \square \square \square \square \square \square \square$

Я, уповноважена посарова особа Міністерства внутрішніх справ України,

ПIБ

ㅁㅁㅁㅁㅁㅁㅁㅁㅁㅁㅁ

Посада

ㅁㅁㅁㅁㅁㅁㅁㅁㅁㅁㅁ

Спеціальне звання

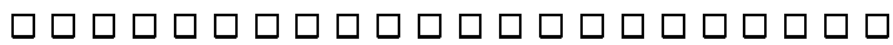

Службове посвілчення

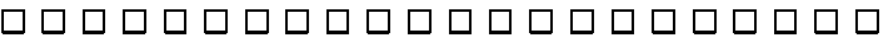

На підставі ст. 254, 255, 256 Кодексу про адміністративні правопорушення України склав цей протокол про те, що громалянин (ка)

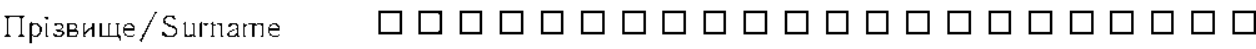
Iм'я/Name

ㅁㅁㅁㅁㅁㅁㅁㅁㅁㅁㅁ

По батькові

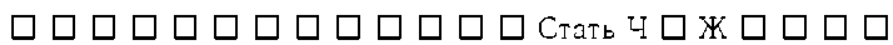

Громадянство/

Nationality

Дата народження ㅁㅁㅁㅁㅁㅁㅁㅁㅁㅁㅁ

Місце народження

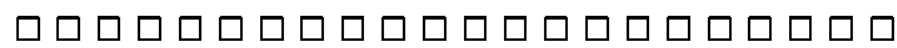

Документ, що посвідчус oco6y

Місце проживання

ㅁㅁㅁㅁㅁㅁㅁㅁㅁㅁㅁ

Телтефон

ㅁㅁㅁㅁㅁㅁㅁㅁㅁㅁㅁ

ㅁㅁㅁㅁㅁ Моб. ㅁㅁㅁㅁㅁ 


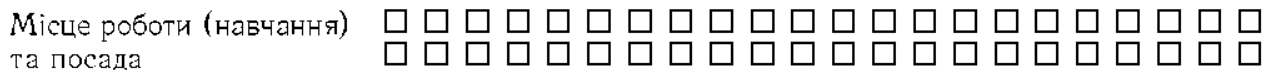

\begin{tabular}{|c|c|}
\hline Вагітність Так $\square$ Ні $\square$ & $\begin{array}{l}\text { Наявність дитини до одного року (для жінок) } \\
\text { Так } \square \text { Нi } \square\end{array}$ \\
\hline ПІБ дитини & ロ \\
\hline Рік народже & ㅁㅁㅁㅁㅁㅁㅁㅁㅁㅁㅁ \\
\hline
\end{tabular}

Відомості про притягнення протятом року до адміністративної відповідальності: Так $\square \mathrm{Hi} \square$ Коли, кнм, за якою ст. КУпАП

Відомості про притягнення особн до крнмінальної відповідальності: Так $\square$ Hi $\square$ Коли, ким, за якою ст. КK України

Учинив адміністративне правопорушення, передбачене ст. 173 Кодексу України про адміністративне правопорушення ("Дрібне хуліганство»), а саме:

Дата $\square \square \square \square \square \square$ Час $\square \square-\square \square$

Micце вчинення правопорушення

Опис протиправних дій вулиця $\square$ парк $\square$ сквер $\square$ будівля, примішення $\square$ підїзд житлового будннку $\square$ стадіон $\square$ дитячнй майданчнк $\square$ громадський транспорт $\square$ підземний перехід $\square$ зупинка маршрутних транспортних засобів $\square$

- нецензурна лайка $\square$

- образливе чіпляння $\square$

- хапання за одяг $\square$

- насильницьке утримання за руки

- демонстративне зривання головного убору $\square$

- вимога дати цигарку або пускання в обличчя диму від неї, непристойна пропозиція дівчнні $\square$

- насильницьке вторгнення в громадські місця всупереч забороні осіб, які слідкують за порядком $\square$

- безпідставне порушення спокою громадян телефонними дзвінками $\square$

- лихослів'я по телефону

- співання непристойних пісень $\square$

- вигуки, свист під час демонстрації кінофільмів $\square$

- і'валт, крики з хуліганських мотивів біля вікон громадян у нічний час $\square$

- справляння природних потреб у не відведених для цього місцях $\square$

- поява у громадському місці в оголеному вигляді

- самовільна без потреби зупннка комунального транспорту $\square$

- нанесення непристойних малюнків на тротуари, стіни, пар-

кани, двері чи вчинення написів нецензурного змісту $\square$

- неправдиве повідомлення про смерть родичів, знайомих,

якщо це призвело до тяжких наслідків $\square$

- інше 
Відомості про свідків правопорушення та потерпілих

Свідок правопорушення:

\begin{tabular}{ll} 
№ & ПІБ \\
1 & \\
\hline Свідок 1 \\
\hline
\end{tabular}

Потерпілий:

No

1

2

Потерпілий 1

ПIБ
Чи заподіяно правопорушенням матеріальну шкоду

Розмір (грн)
Обставини, що пом'якшують відповідальність за адміністративне правопорушення:

щире розкаяння винного вілвернення винним шкілливих насліпків правопорушення, добровільне відшкодування збнтків або усунення заподіяної шкоди продовження протиправної поведінки, незважаючи на вимогу уповноважених на те осіб припинити ї

учинення правопорушення під. впливом сильного душевного хвнлювання або за збігу тяжких особнстих чи сімейних обставин учинення правопорушення неповнолітнім

учинення правопорушення вагітною жінкою або жінкою, яка має дитнну віком до одного року

інше (зазначити)
Обставнни, що обтяжують відповідальність за адміністративне правопорушення: $\square$ учннення правопорушення групою осіб

$\square$ продовження протиправної поведінки, незважаючи на вимогу уповноважених на те осіб прнпинити ऑï

повторне протягом року вчинення однорідного правопорушення, за яке особу вже було піддано адміністративному стягненню

$\square$ утягнення неповнолітнього в правопорушення учннення правопорушення в умовах стихійного лиха або за інших

надзвичайних обставин

$\square$ учинення правопорушення в стані сп'яніння

учинення правопорушення особою, яка раніше вчннила кримінальне правопорушення

Мені роз'яснено зміст статей 55, 56, 59, 63 Конституції України. Мені

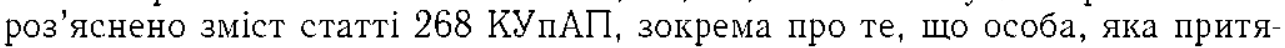
гається до адміністративної відповідальності, має право на таке: знайомитися з матеріалами справи, давати пояснення, подавати докази, заявляти клопотання; при розгляді справи користуватися юридичною допомогою адвоката, іншого фахівця в галузі права, який за законом має право на 
надання правової допомоги особисто чи за дорученням юридичної особи, виступати рідною мовою й користуватися послугами перекладача, якшо не володію мовою, якою ведеться провадження; оскаржити постанову по справі. Справа про адміністративне правопорушення розглядається в присутності особи, яка притягується до адміністративної відповідальності. Під час відсутності цієі особи справу може бути розглянуто лише у випадках, коли $є$ дані про своєчасне ії сповішення про місце ф час розгляду справи і якщо від неї не надійшло клопотання про відкладення розгляду справи.

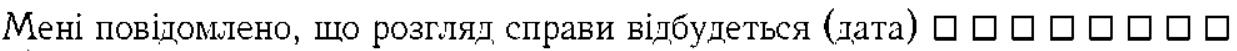
(час) $\square$ ч-口 $\square$ у примішенні

за адресою

Підпис особи, яка притягується до адміністративної відповідальності

Прошу розглянути справу без моєї присутності

Чи проводились під час складання протоколу про адміністративне правопорушення:

Oгляд речей/документів $\square$ Вилучення речей/документів Особистий огляд $\square$

Відомості про вилучені речі / документи:

Поняті

№

ПIБ

Адреса проживання

1

2
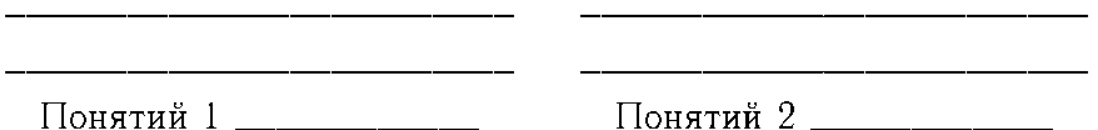

Пояснення особи, яка притягується до адміністративної відповідальності, по суті порушення 


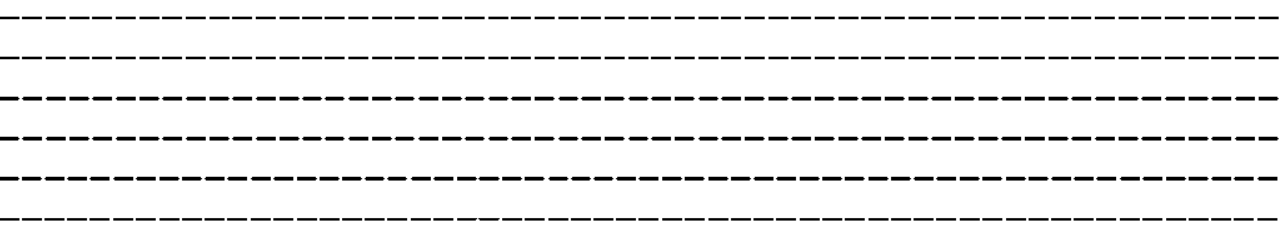

Від пояснення та підпису відмовився (лася) у присутності понятих:

Понятий 1

Понятий 2

Заяви та клопотання:

Рішення керівництва ОВС за заявою, клопотанням

До протоколу додається

Підпис посадової особи, яка склала протокол

Другий примірник протоколу про адміністративне правопорушення отримав

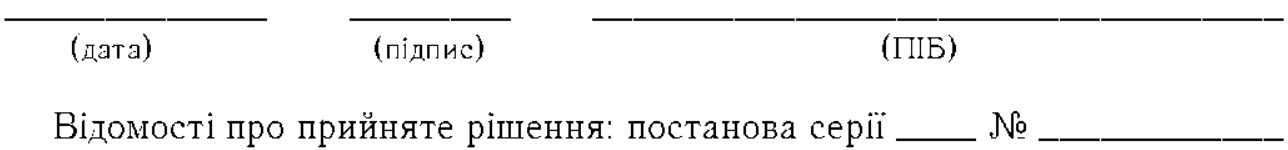
від

\section{Література}

1. Концепція ресформування інстнтуту адміністратнвної відповідальності в Україні |Електронний ресурс]. - Режим доступу : http://pravo.org.ua/publichna-administratsiia/administratyvnedeliktne-pravo / 1030-the-concept-of-reform-of-the-administrative-responsibility-in-ukraine-ua.html.

2. Пархоменко П.І. Особливості протоколу про адміністративне правспорушення у справах про адміністративну відповідальність за керування транспортними засобами / П.1. Пархоменко / / Вісник Академії адвокатурн України. - 2013. - oo 2 (27). - С. 51-56. 
3. Брайченко С.М. Протокол про адміністративне правопорушення та проблеми його складання / С.М. Брайченко // Вісник Запорізького національного університету. - 2012. JNo 4 . - C. $188-193$

4. Vзагальнення практики розгляду справ про адміністратнвні правопорушення за ст. $130 \mathrm{KV}$ пАП України Вінницьким районним судом Вінницької області в 2012 році [Електронний ресурс]. - Режим доступу : http://vnr.vn.court.gov.ua/sud0203/analiz/29957/.

5. Практика розгляду судами справ про адміністративні правопорушення, що посягають на встановленнй порядок управління (ст. 185-185-2 KУПАП) / Верховний Суд VКраїни [Електронннй ресурс]. - Режнм доступу : http://www.scourt.gov.ua/clients/vs.nsf/0/88DE37 EDF92COBE2C32572C900333DF.

6. Узагальнення практики розгляду справ про адміністративні правопорушення за ст. $130 \mathrm{KУ.}$ пАП України Вінницьким районним судом Вінницыкої області в 2012 році [Електронний pecypcl. - Режим доступу : http://vn1.vn.court.gov.ua/sud0203/analiz/29957/.

7. Узагальнення судової практнки шодо порядку розгляду справ про адміністратнвні правопорушення / Миргородський міськрайонний суд Полтавсьзої області [Електронний ресурс]. Режим доступу : http://mrm.pl.court.gov.ua/sud1620/an_dov/uz_adm_pp_1_2012.

8. Узагальнення судової практики щодо порядку розгляду справ про адміністративні правопорушення / Чечельницыкий районний суд Вінницыкої області [Електронний ресурсl. Режнм доступу : http:/ / ch.vn.court.gov.ua/sud0229/uzag/14435/.

9. Судова практика з розгляду адміністративних справ про деяті правопорушення на транспорті / Верховний суд України [Електронний ресурс]. - Режим доступу : http: / / www.scourt. gov.ua/clients/vsu/vsu.nsl/(documents)/152EA8DD0A2095E6C2257B7C00384606.

10. Про якість складання й оформлення судових рішень у кримінальних справах та справах про адміністративні правопорушення / Верховний Суд України (Електронний ресурс]. - Режнм доступу : http://www.scourt.gov.ua/clients/vsu/vsu.nsi/(documents)/DBAE9855550C9F ODC2257B7C00383388.

11. Постансва Скадовсыкого районного суду Херсонсьвої об́ласті від 22 вересня 2009 року. справа № 3-1930/09 [Електронний ресурс]. - Режим доступу : http://www.reyestr.court. gov.ua/Review/4828605.

12. Постанова Бродівського районного суду Львівсыкої об.ласті від 20.11.2014 poky, справа № 439/1955/14-п [Електронний ресурс]. - Режим доступу : http://www.reyestr.court.gov. ua/Review/41567316.

13. Постанова Бродівського районного суду Львівсыкої об.ласті від 22.02 .2011 року, справа Jo 3-207/11 [Електронннй ресурс]. - Режнм доступу : http://www.reyestr.court.gov.ua/ Review/14013855.

14. Постанова Бережанського районного суду Тернопільсьзої області від 26.06.2012 року, справа № 3-395/2012 [Електронний ресурс]. - Режим доступу : http://www.reyestr.coult.gov. ua/Review/27916777.

15. Деякі пнтання виконання Закону України «Про Єднний державний демографічннй реєстр та документн, що підтверджують громадянство Українн, посвідчують особу чн ї̈ спеціальннй статус»: Постанова Кабінету Міністрів України від 13.03.2013 року № 185 [Електронний ресурс]. - Режим доступу: http://zakon2.rada.gov.ua/laws/show/185-2013-п.

\section{Анот а ч я}

Лошuщькuи М. В., Мікка Т. П. Актуальні питання вдосконалення законодавства 3 оформлення матеріалів про адміністративне правопорушення органами внутрішніх справ. - Стаття.

Стаття присвячена дослідженню проблемних питань процесуальної складової в діяльності органів внутрішніх справ України. Досліджуютьея недоліки при складанні протоколів про адміністративні правопорушення, проблеми правильного опнсу протиправних дій особн. Аналізується правозастосовна судова практика в цій сфері. Запропоновано конкретні шляхи вирішення зазначених проблем.

Katotosi chosa: реформування Міністерства внутрішніх справ, адміністративні правопорушення, протокол про адміністративне правопорушення, опис протиправних дій. 


\section{Анн о т а ци я}

Лошицкий М. В., Микка Т. П. Актуальные вопросы усовершенствования законодательства по оформлению материалов об административных правонарушениях органами внутренних дел. - Статья.

Статья посвящена исслерованию проблемных вопросов процессуальной составляющей в деятельности органов внутренних дел Укранны. Исследуются недостатки при составлении протоколов об административных правонарушениях, проблемы правильного описания противоправных действий лица. Анализируется правоприменительная судебная практика в этой сфере. Предложены конкретные пути решения указанных проблем.

Kлюqевые яова: реформирование Министерства внутренних дел, административные правонарушения, протокол об административном правонарушении, описание противоправных действий.

\section{S u in in a r y}

Loshttskiy M. V., Minka T. P. Pressing questions of improvement of legislation on registration of materials in matters about administrative crimes. - Article.

The article investigates issues of procedural component in the internal affairs of Ukraine. We investigate shortcomings in the preparation of reports on administrative offenses correct description of the problem of illegal actions of individuals. Analyzed Enlorcement jurisprudence in this area. Specific solutions to these problems.

Key words: reform of the Interior Ministry, administrative offenses, protocol on administrative offense description unlawful acts. 